\title{
Tree height and tropical forest biomass estimation
}

\author{
M. O. Hunter ${ }^{1}$, M. Keller ${ }^{1,2,3}$, D. Victoria ${ }^{3}$, and D. C. Morton ${ }^{4}$ \\ ${ }^{1}$ Earth Science Research Center, University of New Hampshire, Durham, NH 03824, USA \\ ${ }^{2}$ USDA Forest Service International Institute of Tropical Forestry, San Juan, PR 00926, USA \\ ${ }^{3}$ EMBRAPA Monitoramento por Satélite, Campinas - Sao Paulo, Brazil \\ ${ }^{4}$ NASA Goddard Space Flight Center, Greenbelt, MD 20771, USA \\ Correspondence to: M. O. Hunter (maria.hunter@unh.edu)
}

Received: 5 June 2013 - Published in Biogeosciences Discuss.: 27 June 2013

Revised: 8 October 2013 - Accepted: 19 November 2013 - Published: 20 December 2013

\begin{abstract}
Tropical forests account for approximately half of above-ground carbon stored in global vegetation. However, uncertainties in tropical forest carbon stocks remain high because it is costly and laborious to quantify standing carbon stocks. Carbon stocks of tropical forests are determined using allometric relations between tree stem diameter and height and biomass. Previous work has shown that the inclusion of height in biomass allometries, compared to the sole use of diameter, significantly improves biomass estimation accuracy. Here, we evaluate the effect of height measurement error on biomass estimation and we evaluate the accuracy of recently published diameter-height allometries at four areas within the Brazilian Amazon. As no destructive sample of biomass was available at these sites, reference biomass values were based on allometries. We found that the precision of individual tree height measurements ranged from 3 to $20 \%$ of total height. This imprecision resulted in a 5-6\% uncertainty in biomass when scaled to 1 ha transects. Individual height measurement may be replaced with existing regional and global height allometries. However, we recommend caution when applying these relations. At Tapajos National Forest in the Brazilian state of Pará, using the pantropical and regional allometric relations for height resulted in site biomass $21 \%$ and $25 \%$ less than reference values. At the other three study sites, the pantropical equation resulted in errors of less that $2 \%$, and the regional allometry produced errors of less than $12 \%$. As an alternative to measuring all tree heights or to using regional and pantropical relations, we recommend measuring height for a well-distributed sample of about 100 trees per site. Following this methodology, $95 \%$ confidence intervals of transect biomass were constrained to within $4.5 \%$ on average when compared to reference values.
\end{abstract}

\section{Introduction}

Tropical forests are an important component of global carbon stocks. They contribute an estimated $428 \mathrm{Pg}\left(1 \mathrm{Pg}=10^{15} \mathrm{~g}\right)$ of carbon globally, divided approximately evenly between vegetation and soils (Watson, 2000). This total is approximately one fifth of the global carbon stock, and the vegetation component is one half of the above-ground carbon stored in vegetation of all biomes. However, there is a great deal of uncertainty in these numbers (Watson, 2000). While some of this uncertainty is due to the unknown amount of deforestation and degradation in tropical forests, another large component is due to the uncertainties involved in estimating standing biomass in the field (Houghton, 2005). This uncertainty is compounded when a limited area sampled is used to predict biomass over large tracts of forest.

Because of their high carbon density, tropical forests are increasingly viewed as an avenue for mitigation of climate change. In an effort to reduce deforestation and degradation by creating monetary value for the carbon in forests, the United Nations has developed REDD (Reducing Emissions from Degradation and Deforestation) (Gibbs et al., 2007). However, to implement this framework it is first necessary to quantify carbon stocks.

In an effort to create global biomass maps that can serve as REDD baseline carbon stock estimates, moderate- and coarse-resolution optical and microwave data from satellites has been combined with lidar remote sensing by ICESat to extrapolate field-measured biomass over the global extent of tropical forest (Saatchi et al., 2011; Baccini et al., 2012). Recognizing the importance of biomass estimation the European Space Agency is scheduled to launch the BIOMASS 
radar satellite mission in 2020 in an effort to create three dimensional maps of the world's forests (Le Toan et al., 2011). NASA missions (such as the completed ICESat and the upcoming ICESat II lidar missions) have secondary goals of estimating forest biomass (Lefsky et al., 2007; Nelson, 2010; Saatchi et al., 2011). However, neither existing nor planned remote sensing data sets directly measure biomass; they all rely on field data in combination with allometric estimations for calibration (see further discussion in Clark and Kellner, 2012).

In most applications, estimation of tropical forest biomass is ultimately linked to the estimation of biomass of individual trees (although see Clark and Kellner, 2012, who suggest an alternative approach). Individual tree biomass estimates depend upon allometric equations that are developed using a finite number of individuals from a limited region or a broader combination of sites (Chambers et al., 2001, and others). By necessity, these allometries are often applied beyond the region(s) for which they were developed, and often beyond the range of diameters sampled as well (Chave et al., 2003). Unfortunately, allometric equations do not transfer without error across all sites. For example, Vieira et al. (2008) applied allometric equations developed at sites in the central Amazon and Puerto Rico to Atlantic Forest trees and compared them with an allometry specific to the Brazilian Atlantic Forest. Equations developed at Puerto Rico and the central Amazon deviated by more than $36 \%$ and $68 \%$, respectively, from the Atlantic Forest values. Recently, broader analyses have been conducted that create regional and global allometric relations based on data from multiple sites (Chave et al., 2005; Feldpausch et al., 2012). These allometries are based on significantly larger sample sizes, and are assumed to be more robust for regions without site-specific equations. The Chave et al. (2005) allometry uses stem diameter and wood density, and optionally total tree height. Feldpausch et al. (2011) have developed global and regional equations to relate height to diameter for sites where height measurements are lacking.

Studies in temperate and tropical regions have shown the advantages of species-specific biomass and volume allometries (Basuki et al., 2009; Litton and Kauffman, 2008). Given the variation in tree form and growth properties, speciesspecific allometries are desirable. However, the species diversity present in tropical forests makes this prohibitively costly for most sites. For example, a study conducted near Manaus showed 280-285 species per hectare for three hectares sampled for trees greater than $10 \mathrm{~cm}$ diameter (De Oliveira and Mori, 1999). Sites in the Brazilian Amazon typically have upwards of 100 tree species per hectare (Campbell et al., 1986), most of which do not have species-specific allometries.

The inclusion of height in allometric equations greatly improves the accuracy of individual tree biomass estimation (Chave et al., 2005; Feldpausch et al., 2012; Lima et al., 2012; Maia Araújo et al., 1999; Vieira et al., 2008). Chave et al. (2005) reported that the inclusion of height for stand level estimates of biomass reduced error from $19.5 \%$ to $12.8 \%$, across all forms of tropical forests and across continents. At Brazilian sites specifically, the root mean squared error (RMSE ) of individual tree biomass was reduced from $16 \%$ to $6 \%$.

The accuracy of biomass estimation for individual trees and subsequently for plot scale biomass fundamentally depends on the accuracy of tree height measurements. Tree heights can be difficult to measure under the best conditions (Rennie, 1979; Williams et al., 1994). Height measurements are dependent on forest conditions, observer experience, and the equipment used. Tropical forests typically include significant obstacles for traditional field-based estimates of tree heights, including dense understory vegetation, tall canopies, and closed-canopy conditions that limit the line of sight. Tree height measurements in tropical forests both are labor intensive and have potentially large errors. Although researchers agree that height is a valuable addition when estimating biomass, the degree of acceptable error has been debated. Williams and Schreuder (2000) compared a diameter-only allometry to a diameter-height allometry and found that a height error of up to $40 \%$ was acceptable in temperate forests before the use of a diameter-only equation provided a better biomass estimate. Molto et al. (2012) showed that a height error of $2-5 \%$ can significantly influence estimates of aboveground biomass for a tropical forest in French Guiana. We evaluate how tree height accuracy affects biomass estimation accuracy for moist tropical forests in Brazil by responding to a number of questions.

- How precise are ground-based tree height measurements using a handheld clinometer and metric tape?

- How accurate are ground-based tree height measurements using the clinometer approach?

- What is the effect of tree-level uncertainty in height on the estimation of plot biomass?

- Are global and/or regional height-diameter relations adequate for accurate biomass estimation?

- How can field work be optimized to achieve acceptable accuracy in plot-level biomass while limiting the number of tree height measurements used?

\section{Methods}

\subsection{Site descriptions}

Data from five sites in four regions of contrasting forest structure distributed across the Brazilian Amazon were used to answer the questions posed above. The precision of groundbased tree height measurements was evaluated by comparing repeat measurements of height at one of the field sites, Tapajos km 67. The accuracy of height measurements was evaluated by comparing field and lidar data at the Tapajos sites and 
at Reserva Ducke. The resulting estimates of accuracy were applied at Tapajos sites and at Reserva Ducke to answer the third question, and the remaining questions were addressed using field data from all sites (see Table 1 schematic).

Regional and pantropical height-diameter allometries published by Feldpausch et al. (2011) include local climate and structural parameters. Climate data for all sites were extracted from the WorldClim $2.5 \mathrm{~min}$ resolution database (Hijmans et al., 2005) in order to remain consistent with climate data requirements proposed by Feldpausch et al. (2011) and are presented in Table 2 . The precipitation variability was defined as the standard deviation of monthly precipitation divided by the mean. Dry season length was defined as the number of months with less than $100 \mathrm{~mm}$ of precipitation.

Forest structural characteristics derived from field data are presented in Table 3. Basal area, maximum diameter measured and mean canopy height all vary among sites. The mean canopy height was calculated from field data as Lorey's height (basal-area-weighted mean height).

\subsubsection{Reserva Adolpho Ducke}

Reserva Adolpho Ducke (59 $57^{\prime} \mathrm{W} 2^{\circ} 57^{\prime} \mathrm{S}$ ) is a 10000 ha forest preserve managed by the National Institute for Amazon Research (INPA) north of Manaus, Brazil. It is dominated by rolling terrain (30-120 m a.s.l.) cut by small streams and covered by upland terra firme forest with a large number of palms present, especially in seasonally flooded valleys. The soils vary with topography with oxisols similar to those of Tapajos National Forest (see below) present on the upland plateaus, ultisols on the slopes and spodosols in the valleys (Chauvel et al., 1987). These soils are acidic and low in nutrients. Mean annual temperature is $27^{\circ} \mathrm{C}$, and precipitation averages $2208 \mathrm{~mm}$ with a short dry season (1-3 months) during July-September (Table 2).

\subsection{Tapajos National Forest - Tapajos km 67 and Tapajos km 83}

The Tapajos National Forest $\left(54^{\circ} 58^{\prime} \mathrm{W}, 2^{\circ} 51^{\prime} \mathrm{S}\right)$ is a 550000 ha reserve situated south of Santarém, Brazil, between the Tapajos River and the Cuiabá-Santarém Highway (BR-163). The reserve is dominated by upland forests on a nutrient-poor, clay oxisol plateau (Silver et al., 2000). The mean annual temperature and precipitation at Tapajos are $25^{\circ} \mathrm{C}$ and $1909 \mathrm{~mm}$, respectively. The dry season generally lasts five months, from July to December (Vieira et al., 2004). Two field sites were installed within the Tapajos National Forest referred to by their entrance points along the BR-163 highway: an undisturbed forest site (Tapajos km 67) and a selectively harvested site (Tapajos km 83).

\subsubsection{Fazenda Tanguro}

Fazenda Tanguro $\left(52^{\circ} 23^{\prime} \mathrm{W} 13^{\circ} 4^{\prime} \mathrm{S}\right)$ is a private land holding of approximately 80000 ha within the municipality of
Querência, Mato Grosso. Located near the forest-cerrado transition, Fazenda Tanguro is classified as transitional forest characterized by comparatively low biomass and tree species diversity. Soils are oxisols throughout this generally flat region, with slopes less than $2^{\circ}$ (Balch et al., 2008). It has a mean temperature of $25^{\circ} \mathrm{C}$, annual precipitation of approximately $1740 \mathrm{~mm}$ and a 5-6-month dry season lasting from May to September (Balch et al., 2010). Though the annual temperature and dry season length are similar to that of Tapajos, the variability in precipitation is much higher at Tanguro.

\subsubsection{Fazenda Cauaxí}

Fazenda Cauaxí is a mainly forested land holding in the municipality of Paragominas in eastern Pará state $\left(48^{\circ} 17^{\prime} \mathrm{W}\right.$ $3^{\circ} 45^{\prime} \mathrm{S}$ ). The topography of this area is flat to mildly undulating and is characterized by tropical dense moist forest with a mean temperature of $27^{\circ} \mathrm{C}$, annual precipitation averaging $2200 \mathrm{~mm}$ and a 5-6-month dry season from July through November (Pereira et al., 2002). The soils within the region are classified as dystrophic yellow latosols following the Brazilian system (Radambrasil, 1983).

\subsection{Field inventory measurements}

\subsubsection{Reserva Adolpho Ducke}

Five $500 \mathrm{~m}$ transects were installed at Reserva Ducke in October of 2009. Diameter-dependent line sampling using a diameter factor of 10.0 (following Schreuder et al., 1987) was conducted along each $500 \mathrm{~m}$ transect including trees greater than $5 \mathrm{~cm}$ diameter. A total of 817 living trees were sampled at Reserva Ducke. The resulting average nominal plot size was approximately $0.6 \mathrm{ha}$, calculated as the average maximum distance from the transect times transect length.

Stems were mapped with respect to the transect, and geolocated using differential global navigation satellite system (GNSS; Trimble GeoXH 6000 series receivers with estimated post-processed accuracy of $<0.5 \mathrm{~m}$ using Trimble Pathfinder Office V.5 software). Four differential GNSS (dGNSS) points were taken along each transect at roughly equal intervals. Individual tree positions were calculated using the two closest dGNSS points to any given stem.

For each stem, diameter at breast height (DBH), total height and crown extent were measured. Where buttresses or trunk deformities were present, diameter was measured above the deformation. Total height and bottom-of-canopy height were measured using a clinometer and tape measure and calculated trigonometrically. The clinometer is used to measure the angle to the canopy top and bottom as well as the angle from the viewer to the base of the trunk. All angles measured were under $50^{\circ}$ to minimize error within the trigonometric calculation. A tape measure was used to measure the distance from the observer to the measurement point. In the case of measurements on sloped ground, the slope of 
Table 1. Data used to address each of the five questions posed by this research. Lidar data were available for three of the five sites.

\begin{tabular}{|c|c|c|c|c|c|c|c|c|}
\hline \multirow{2}{*}{$\begin{array}{l}\text { Site } \\
\text { Data Available }\end{array}$} & \multicolumn{2}{|c|}{ Reserva Ducke } & \multicolumn{2}{|c|}{ Tapajos km 67} & \multicolumn{2}{|c|}{ Tapajos km 83} & \multirow{2}{*}{$\begin{array}{c}\text { Tanguro } \\
\text { Field }\end{array}$} & \multirow{2}{*}{$\begin{array}{c}\text { Cauaxí } \\
\text { Field }\end{array}$} \\
\hline & Field & Lidar & Field & Lidar & Field & Lidar & & \\
\hline Q1. Precision of ground-based height measurements & & & $\mathrm{X}$ & & & & & \\
\hline Q2. Accuracy of ground-based height measurements & $\mathrm{X}$ & $\mathrm{X}$ & $\mathrm{X}$ & $\mathrm{X}$ & $\mathrm{X}$ & $\mathrm{X}$ & & \\
\hline Q3. Effect of height uncertainty on biomass prediction & $\mathrm{X}$ & $\mathrm{X}$ & $\mathrm{X}$ & $\mathrm{X}$ & $\mathrm{X}$ & $\mathrm{X}$ & & \\
\hline Q4. Use of global/regional diameter-height allometries & $\mathrm{X}$ & $\mathrm{X}$ & $\mathrm{X}$ & $\mathrm{X}$ & $\mathrm{X}$ & $\mathrm{X}$ & $\mathrm{X}$ & $\mathrm{X}$ \\
\hline Q5. Optimization of field data collection & $\mathrm{X}$ & $\mathrm{X}$ & $X$ & $X$ & $X$ & $X$ & $X$ & $X$ \\
\hline
\end{tabular}

the tape measure was also measured and the distance corrected. Heights were calculated trigonometrically. All height measurements were taken by a single observer. Crown radius was measured in four cardinal directions with respect to the trunk. Notes were taken on the availability of light to the tree crown (full direct, partial direct, full indirect light) and the crown's position within the canopy (emergent, canopy or subcanopy). Emergent trees were defined as those standing above the surrounding tree's canopies, not those taller than the dominant canopy height. While multiple life forms (including vines and palms) and standing dead trees were included in the field sampling; only the living trees were analyzed.

\subsubsection{Tapajos National Forest - Tapajos km 67 and Tapajos km 83}

A total of twelve $500 \mathrm{~m}$ transects were installed: six within the old-growth portion (Tapajos km 67) of Tapajos National Forest in June 2009, and another six in a selectively logged portion (Tapajos $\mathrm{km} \mathrm{83)} \mathrm{in} \mathrm{January} \mathrm{2010.} \mathrm{The} \mathrm{sampling}$ method and measurements at the Tapajos sites were the same as at Reserva Ducke (see Sect. 2.2.1). A total of 1765 living trees were sampled at Tapajos, with a resulting average nominal plot size of 0.85 ha.

Geolocation of individual stems at the Tapajos sites differed from the methods at Reserva Ducke. Stems were mapped with respect to the transect, and geolocated using differential GNSS (Trimble GeoXH 6000) in combination with data collected using handheld GPS units (Garmin $76 \operatorname{csx}$ ). Differential GNSS was used to collect a point at the start of each transect and handheld GPS measurements taken at $50 \mathrm{~m}$ increments. Handheld GPS points were used to determine the orientation of the transect. At two transects a greater density of differential GNSS was available (approximately six points spaced every $100 \mathrm{~m}$ along the transect) and transect and tree positions were compared to the single dGNSS point in combination with handheld GPS data. Transect positions varied up to $19.2 \mathrm{~m}$ and individual trees had a horizontal RMS error of $5.7 \mathrm{~m}$.

During the survey of Tapajos $\mathrm{km} 67$ a random subset of $20 \%$ of trees (174 individuals) was remeasured within a week of the initial survey. Diameter at breast height, bottom- of-canopy height, top-of-canopy height and light characteristics were all remeasured to assess the repeatability of field measurements. Remeasurement of all stems at this site occurred in July 2010.

\subsubsection{Fazenda Tanguro}

Eighteen 0.37 ha circular plots were installed in 2005, designed for correlation with satellite-based lidar footprints (ICESat-GLAS). Further sampling design information is available in Lefsky et al. (2005). Total height, commercial height (height to lowest branch) and longest crown dimension of all trees greater than $35 \mathrm{~cm}$ diameter were measured. Trees with 10 to $35 \mathrm{~cm}$ diameter were measured in a subplot of 0.075 ha, with a random subset of $20 \%$ selected to measure canopy characteristics. Both total and commercial height were measured using a clinometer and tape measure.

\subsubsection{Fazenda Cauaxí}

Fourteen 1 ha plots $(500 \mathrm{~m} \times 20 \mathrm{~m}$ transects $)$ were surveyed at Fazenda Cauaxí in 2000 for trees greater than $20 \mathrm{~cm}$ diameter, totaling 2271 individuals (Asner et al., 2002, 2012). Additional crown measurements were taken for a subset of 300 stems. These crown measurements included top-of-canopy height, commercial height and crown width along the estimated longest axis. See Asner et al. (2002) for the complete methodology. Tree heights were estimated using a handheld laser range finder (Impulse-200LR, Laser Technology Inc., Englewood, $\mathrm{CO}$ ) that measures distance using laser ranging and estimates height using a clinometer incorporated into the instrument.

\subsection{Airborne lidar data}

Airborne lidar data were collected over Tapajos National Forest and Reserva Ducke between 7 June and 3 July 2008 by Esteio, Ltda. (Curitiba, Parana, Brazil) using a Leica ALS50 discrete-return lidar system capable of capturing four returns per outgoing pulse. Flights were conducted between 700 and $900 \mathrm{~m}$ above ground level, resulting in a footprint diameter of $15-20 \mathrm{~cm}$. The instrument was operated with a two-sided scan angle of 30 degrees. Minimum pulse densities of 10 pulses $\mathrm{m}^{-2}$ were specified at Tapajos km 67 and 
Reserva Ducke and 3 pulses $\mathrm{m}^{-2}$ at Tapajos km 83. With up to 4 returns per outgoing pulse and flight line overlaps, mean return densities of 46.7 points $\mathrm{m}^{-2}$ for high-density sites and 12.1 points $\mathrm{m}^{-2}$ for low-density sites were observed. Position errors were tested using overlapping data from multiple flight lines. Features identifiable in both scenes, such as the crown edges of emergent trees, were used to estimate position error. Mean differences did not exceed $70 \mathrm{~cm}$ vertical and $40 \mathrm{~cm}$ horizontal. This is an extremely conservative estimate of point accuracy as it includes both the geolocation error and error due to the likelihood of repeat sampling of the exact same point within the tree crown.

The lidar point cloud was summarized to create a digital terrain model (DTM) and canopy height model (CHM). The DTM was created by first separating ground returns following the algorithm of Zhang et al. (2003). The density of ground returns was 0.44 per $\mathrm{m}^{2}$ at Tapajos $\mathrm{km} \mathrm{67,0.19}$ at Tapajos km 83 and 0.83 per $\mathrm{m}^{2}$ at Reserva Ducke. Using a similarly high density of data collection and the same methods for constructing a DTM (1 m grid), a mean error of less than $10 \mathrm{~cm}$ was achieved (V. Leitold, personal communication, 2013). Delauney triangulation was used to create a triangular irregular network (TIN) of ground hits, and the TIN was then used to interpolate DTM elevations on a raster grid of $1 \mathrm{~m}$ spatial resolution. Additionally, the TIN was used to interpolate the elevation of every feature return in every grid cell, and feature heights were calculated as the difference from this elevation (Cook at al., 2013). The CHM was created by selecting the greatest height of all non-ground return points within a given $1 \mathrm{~m}$ grid cell (minimum of 3 returns per grid cell).

\subsection{Lidar estimation of tree heights}

Georeferenced crown locations were used to estimate tree heights from the lidar data at the Tapajos and Reserva Ducke sites. For each crown, an ellipse of crown inclusion was created based on four crown radii measured in the field in combination with the georeferenced trunk position (Fig. 1). The 99th-percentile height of the lidar data within each crown ellipse was defined as the lidar-estimated maximum tree height.

The comparison of lidar height to field height measurements was limited to emergent stems, as they are expected to be visible in the lidar canopy height model (Fig. 3). Emergent stems were considered to be any tree whose canopy is above its immediate neighbors. To assess the extent to which the time period between lidar and field data collections may affect our results, we compared field heights of emergent trees measured with a one-year intersample period at Tapajos km 67.

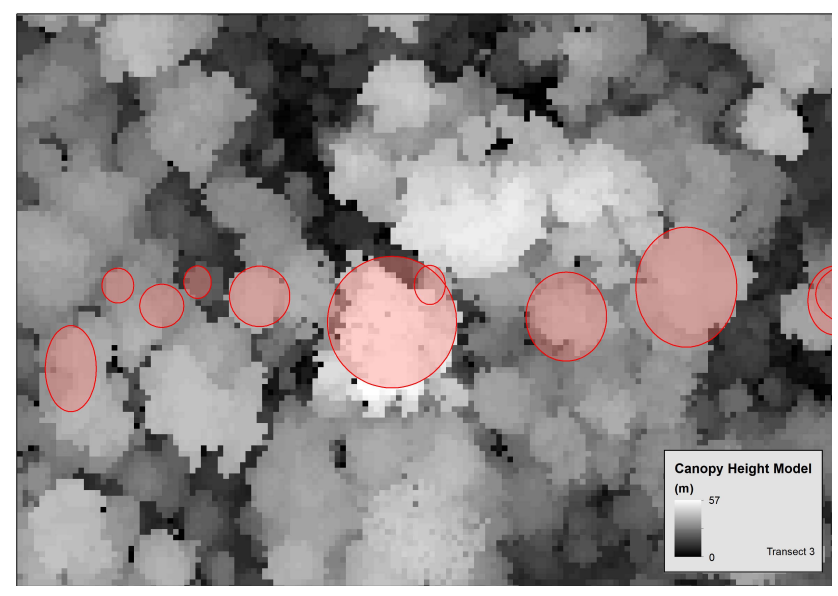

Fig. 1. The canopy height model is shown for a region of Tapajos $\mathrm{km} 67$, with darker shades of grey corresponding to lower canopy heights. Field data collected along a transect within this area include four measurements of crown radius and position. These field data were used to draw crown ellipses for emergent stems that are overlaid on the canopy height model.

\subsection{Statistical analysis and simulation}

To analyze the effect of the uncertainty in tree height on biomass estimates, a Monte Carlo analysis was conducted. Stems with multiple measurements at Tapajos $\mathrm{km} 67(n=$ 174) were split into four diameter classes with an equal number of stems: $5-7.3 \mathrm{~cm}, 7.4-13.7 \mathrm{~cm}, 13.8-33.4 \mathrm{~cm}$, and greater than $33.5 \mathrm{~cm}$. The standard deviation of the differences between initial and repeat height measurements was calculated for each class. Returning to the full data set, a series of random numbers normally distributed with a mean of zero and a standard deviation matching that of the height difference within each diameter class was calculated. A random number from this distribution was added to each field height measurement, and the Chave Model I (Chave et al., 2005) moist forest allometry was then used to recalculate biomass for each stem, using a site average wood density of 0.64 . The simulation was conducted 1000 times, and the resulting transect-level biomass was reported.

To assess the necessity of time-consuming height measurements at individual sites, site-specific diameter-to-height allometric relationships were compared with the best regional and pantropical allometries published by Feldpausch et al. (2011). Feldpausch et al. (2011) found that environmental and structural parameters significantly improved diameter-height allometries. Both the regional and pantropical allometries include environmental (Table 2) and structural parameters (Table 3) that are site-dependent. Tapajos sites were combined as they have the same inherent structure, and the basal area of Tapajos $\mathrm{km} 67$ was used to calculate regional and pantropical allometries as the basal area at Tapajos $\mathrm{km} 83$ was reduced due to selective harvest. Site-specific 
allometries were fit to a $\log -\log$ formulation following Feldpausch et al. (2011) using all field measurements of height. Individual stems were weighted evenly within each of four diameter classes, determined by the range of diameters sampled at a given site. The range of diameters used to determine the four diameter classes spans from the minimum to the 99th percentile of diameters measured. In order to divide the diameters into bins, the full range is further divided into fractional subranges: $0-0.22,0.22-0.35,0.35-0.51,0.51-1.0$. Although these four diameter classes are weighted equally, the first three subranges are divided in half to further distribute the sample.

At sites where heights were measured for all trees (Tapajos sites and Reserva Ducke), reference values for site and transect-level biomass were calculated using field-measured height. At Tanguro and Cauaxí reference values for biomass were calculated by applying the site-specific diameter-height allometries. To determine the approximate sample size of tree height necessary to estimate biomass within $5 \%$ of the value calculated based on all trees, bootstrap resampling was applied. For a given sample size, the entire data set was subset 1000 times (sampling without replacement within each subset) and allometries were fit to each subset. The weighting scheme applied for the site-specific fit was also applied to sample stems by diameter class. To determine the given allometry's accuracy in terms of biomass prediction, field data were regrouped to compare approximately 1 ha sized plots in all cases.

\section{Results}

\subsection{Precision of ground-based height measurements}

Remeasurement of 174 stems from the Tapajos km 67 field survey showed no significant difference from zero between the first and second measurements $(t$ test $p=0.38)$. The overall mean difference in height (first measurement minus second measurement) was $1.1 \mathrm{~m}$, with a standard deviation of $4.7 \mathrm{~m}$. There was a slight tendency toward lower remeasured heights (i.e., positive residuals) both overall and by diameter class (Fig. 2). The difference between first and second measurements was an average of $16.57 \%$ of the mean height measured (median of $11.9 \%$ ). Dividing the remeasured heights into four diameter classes with an equal number of samples, the standard deviation of height differences within individual size classes increases by a factor of eight from $1.09 \mathrm{~m}$ to $8.17 \mathrm{~m}$. This represents an increase in relative terms as well as absolute terms and suggests that field measurements of tall trees are less precise than those of short trees.

\subsection{Accuracy of field measurements of height compared to lidar}

The height difference between emergent crowns measured in the field versus the height estimated using lidar was $-1.4 \mathrm{~m}$ (lidar - field height). The mean residual of lidar minus field height was $-1.3 \mathrm{~m}$ at Reserva Ducke (standard deviation of $6.4 \mathrm{~m}$ ), $-2.0 \mathrm{~m}$ at Tapajos $\mathrm{km} 67$ (standard deviation of $8.9 \mathrm{~m}$ ), and $-0.9 \mathrm{~m}$ at Tapajos $\mathrm{km} 83$ (standard deviation of $6.6 \mathrm{~m})$. There are two possible explanations of these differences. One possibility is an overestimation of field height; the second possibility is an underestimation by lidar. A third possible explanation, that sampled trees grew during the time period between lidar and field data collections, was discarded. Comparing field heights of emergent trees measured at Tapajos $\mathrm{km} 67$ with a one-year intersample period showed no significant difference in mean heights (paired $t$ test $p=0.34$ ). Height residuals (lidar minus field height) show a slight positive trend when regressed against lidar height. This is consistent with the observation that heights are increasingly difficult to measure above the dominant forest canopy (34 $\mathrm{m}$ at Tapajos and $25 \mathrm{~m}$ at Reserva Ducke). However, the uncertainty of field measurements is larger than the mean residual in all cases.

\subsection{Effect of height error on plot-level biomass}

At Tapajos the $95 \%$ confidence interval of transect-level biomass due to variability in field estimated heights ranged from 13 to $22 \mathrm{Mg} \mathrm{ha}^{-1}$, with transect biomass estimates ranging from 147 to $398 \mathrm{Mg} \mathrm{ha}^{-1}$ (Table 4). The mean biomass is lower and more variable at Tapajos $\mathrm{km} 83$ $\left(288 \mathrm{Mg} \mathrm{ha}^{-1}\right)$ as compared with the old-growth site Tapajos $\mathrm{km} 67\left(325 \mathrm{Mg} \mathrm{ha}^{-1}\right)$. Typically, transects with higher biomass show a larger $95 \%$ confidence interval and smaller error in terms of percent biomass, although this is dependent on the size distribution of individual trees. The $95 \%$ confidence interval as a percentage of biomass ranged from $5.2 \%$ to $8.7 \%$ with a mean of $6.3 \%$.

Although repeat field measurements were not available for Reserva Ducke, the height error estimated at Tapajos was applied to estimate variability due to the lack of precision of field measurements. The $95 \%$ confidence interval of transect biomass ranged from 17 to $21 \mathrm{Mg} \mathrm{ha}^{-1}$, with biomass estimates ranging from 306 to $431 \mathrm{Mg} \mathrm{ha}^{-1}$. Based on these calculations the lack of precision in height measurements results in a $95 \%$ confidence interval of $5.0 \%$ to $5.7 \%$ of biomass.

To test the effect of the potential bias towards overestimating field height, the mean residual was subtracted from trees within $10 \mathrm{~m}$ of the mean canopy height and above. This shrank the height of canopy and emergent trees by $1.82 \mathrm{~m}$ at Tapajos and $1.23 \mathrm{~m}$ at Reserva Ducke, resulting in an average decrease of $4.1 \%$ of transect-level biomass at Reserva Ducke and an average decrease of $3.5 \%$ at Tapajos. 
Table 2. Site locations and climatic characteristics.

\begin{tabular}{|c|c|c|c|c|c|}
\hline Site & Reserva Ducke & Tapajos km 67 & Tapajos km 83 & Tanguro & Cauaxí \\
\hline Location & $59^{\circ} 57^{\prime} \mathrm{W} 2^{\circ} 57^{\prime} \mathrm{S}$ & $54^{\circ} 57^{\prime} \mathrm{W} 2^{\circ} 51^{\prime} \mathrm{S}$ & $54^{\circ} 58^{\prime} \mathrm{W} 3^{\circ} 01^{\prime} \mathrm{S}$ & $52^{\circ} 23^{\prime} \mathrm{W} 13^{\circ} 04^{\prime} \mathrm{S}$ & $48^{\circ} 17^{\prime} \mathrm{W} 3^{\circ} 45^{\prime} \mathrm{S}$ \\
\hline Mean annual temperature $(\mathrm{C})$ & 27 & 25 & 25 & 25 & 27 \\
\hline Average precipitation (mm) & 2208 & 1909 & 1909 & 1740 & 2200 \\
\hline Precipitation variability (\%) & 33 & 45 & 45 & 79 & 85 \\
\hline Dry season length (months) & 1 & 5 & 5 & 5 & 6 \\
\hline
\end{tabular}

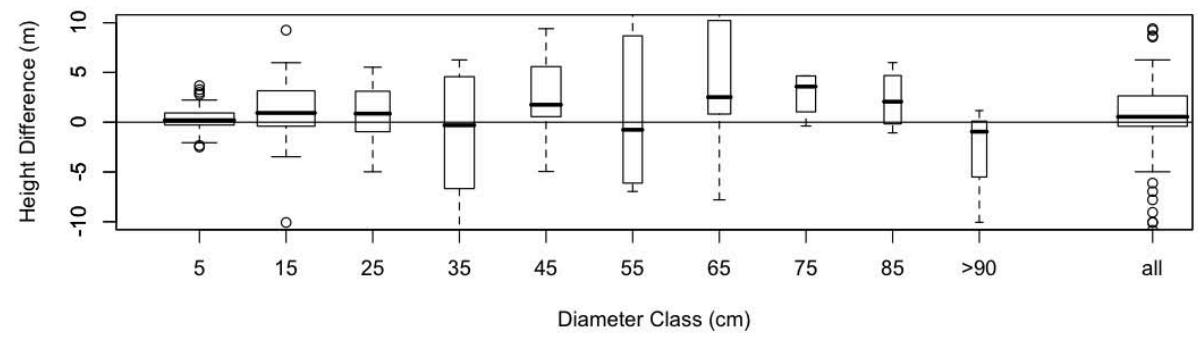

Fig. 2. Height measurements were repeated for 174 trees during the 2009 field campaign at Tapajos km 67 . Box width is proportional to the square root of the sample size. The mean height difference for all remeasured trees is $1.1 \mathrm{~m}$, with a standard deviation of $4.7 \mathrm{~m}$.

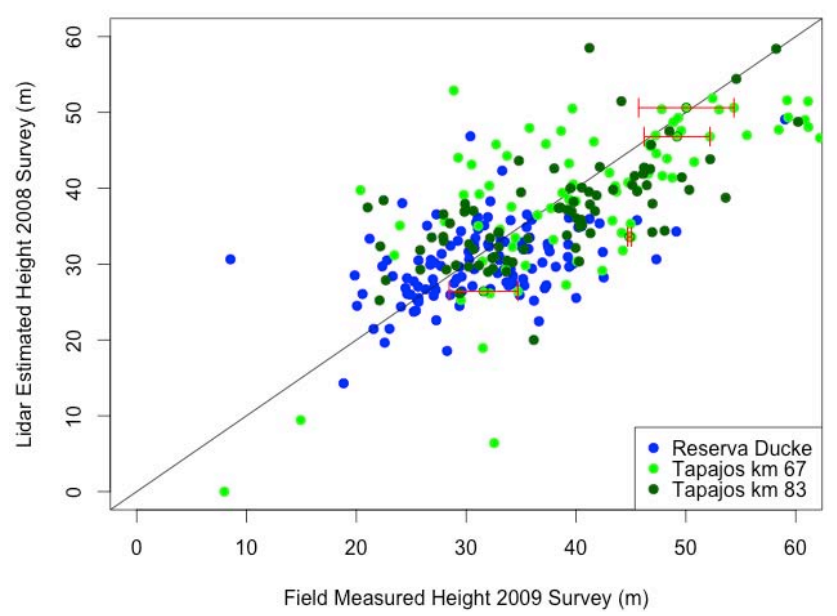

Fig. 3. Comparison of field-measured height to that estimated using the lidar canopy height model (CHM) for stems with emergent crowns at Reserva Ducke and Tapajos sites (Tapajos km 67 and Tapajos km 83). RMSE of emergent crowns is $7.3 \mathrm{~m}$. Where multiple field heights were taken for emergent stems, mean values are shown with error bar showing the range of repeated measurements.

\subsection{Height prediction via allometry}

The variability in the diameter and height ranges between sites was large, with maximum heights varying between 39 and $66 \mathrm{~m}$, and maximum diameters ranging from 70 to $213 \mathrm{~cm}$. This variability is indicative of some of the variation in site-specific diameter-to-height allometries. Two of the sites evaluated are within the eastern-central Amazon region (Tapajos and Reserva Ducke), whereas the Cauaxí and
Tanguro sites are within the Brazilian Shield according to the classification of Feldpausch et al. (2011).

Pantropical and regional allometries resulted in substantial differences in estimated heights and biomass at both the individual tree and transect scales (Fig. 4). At all sites, heights calculated using generalized allometries were compared with heights modeled using site-specific allometries based on all field-measured heights. At Tapajos the pantropical and regional allometries estimated tree heights as $22 \%$ and $27 \%$ less than the field-height-based model, with percentages calculated by evenly weighting across all diameter classes. Pantropical and regional allometries performed better at Reserva Ducke. There, the height estimate based on the pantropical equation was $1 \%$ higher than the field-heightbased allometry, whereas the regional equation resulted in height estimates $12 \%$ lower.

At Tanguro and Cauaxí, both sites within the Brazilian Shield, the generalized allometries performed well. At Tanguro, the pantropical equation fit the site extremely well, with an average height $0.3 \%$ higher than the field-height-based allometry. The regional equation also performed relatively well at this site, averaging a $4 \%$ overestimation. At Cauaxí, the regional and pantropical equations also performed well, with heights $1 \%$ higher than the field-height-based allometry using the regional equation and $1 \%$ lower when using the pantropical allometry.

Applying these height allometries to the estimation of biomass, the regional Feldpausch allometry was 25\% lower than the reference biomass at Tapajos and $12 \%$ lower at Reserva Ducke. The same allometry resulted in higher estimates of biomass at Tanguro (by $4 \%$ ) and at Cauaxí (by $1 \%)$. The pantropical allometry resulted in lower estimates 
Table 3. Details of field and lidar data collection. Lidar data were collected for three of the five sites: Reserva Ducke, Tapajos km 67 and Tapajos km 83. Lorey's height is the basal-area-weighted mean canopy height for all trees measured. (The nominal sample area of the field survey is reported at Tapajos and Reserva Ducke sites, as diameter-dependent line sampling was conducted.)

\begin{tabular}{|c|c|c|c|c|c|}
\hline Site & Reserva Ducke & Tapajos km 67 & Tapajos km 83 & Tanguro & Cauaxí \\
\hline Number of trees measured $(\mathrm{N})$ & 817 & 913 & 852 & 844 & 2171 \\
\hline Tree heights measured $\left(\mathrm{N}_{\mathrm{ht}}\right)$ & 817 & 913 & 852 & 308 & 306 \\
\hline Area sampled (ha)* & 3 & 5.1 & 5.1 & 6.66 & 14 \\
\hline Basal area $(\mathrm{m} 2 \mathrm{ha}-1)$ of trees $>=10 \mathrm{~cm}$ diameter & 28.7 & 31 & 17.6 & 17.1 & 35.2 \\
\hline Diameter range measured $(\mathrm{cm})$ & $5-128$ & $5-213$ & $5-186$ & $10-70$ & 20-192 \\
\hline Lorey's height (m) & 30 & 38 & 38 & 19 & 39 \\
\hline Date of field data collection & $10 / 2009$ & 06/2009 & $01 / 2010$ & $11 / 2005$ & $07 / 2000$ \\
\hline Area of lidar data collected (ha) & 1200 & 400 & 768 & NA & NA \\
\hline Mean CHM height (m) & 25 & 34 & 34 & NA & NA \\
\hline Date of lidar data collection & $06 / 2008$ & $06 / 2008$ & $06 / 2008$ & NA & NA \\
\hline
\end{tabular}

Table 4. Transect live biomass and $95 \%$ confidence interval due to height uncertainty as calculated using the Monte Carlo analysis described in Sect 2.5.

\begin{tabular}{lccc}
\hline Site & Transect & $\begin{array}{c}\text { Biomass } \\
\left(\mathrm{Mg} \mathrm{ha}^{-1}\right)\end{array}$ & $\begin{array}{c}95 \% \\
\text { confidence interval }\end{array}$ \\
\hline Tapajos km 83 & 1 & 344 & 20 \\
& 2 & 310 & 18 \\
& 3 & 350 & 21 \\
& 4 & 314 & 17 \\
& 5 & 263 & 17 \\
& 6 & 146 & 13 \\
\hline Tapajos km 67 & 1 & 267 & 18 \\
& 2 & 365 & 22 \\
& 3 & 318 & 22 \\
& 4 & 267 & 17 \\
& 5 & 339 & 21 \\
& 6 & 398 & 21 \\
\hline Reserva Ducke & 1 & 361 & 19 \\
& 2 & 306 & 17 \\
& 3 & 336 & 19 \\
& 4 & 431 & 21 \\
\hline
\end{tabular}

of biomass at Tapajos (by $21 \%$ ), Reserva Ducke (by $1 \%$ ) and Cauaxí (by 2\%). This allometry yielded biomass estimates $1 \%$ above the reference value at Tanguro. Reference biomass values were calculated using individual field-measured tree heights at Tapajos and Reserva Ducke, and site-specific allometries based on all field-measured heights at Tanguro and Cauaxi (Table 3).

\subsection{Optimization of height measurement for biomass prediction}

We ask whether local measurements of height-diameter relationships are important to improve biomass estimates in tropical forests and, if so, how much effort must be put into local estimation. Sample sizes of 40, 60, 80 and 100 trees were tested for each of the four sites. For each sample, an equal number of trees were chosen from each of four diameter classes (defined in Sect. 2.5). A subset of 40 trees resulted in $95 \%$ confidence intervals of transect biomass of 7-10\% across sites. Increasing the sample to 100 trees decreased this variability to between 4 and $6 \%$ at all sites. As expected, as the sampled number of trees increased, the allometry became increasingly consistent with that found for all stems (Fig. 5). Likewise, the variance in biomass estimates due to the differences in allometry converged.

\section{Discussion}

We aimed to evaluate how precisely and how accurately we could measure tree height on the ground. We then evaluated how the uncertainty in tree height measurements translated into uncertainty in biomass estimates. Because height is important for biomass estimation, we evaluated the accuracy of global or regional allometries. That evaluation suggests caution when employing those relations. We evaluated a laborefficient alternative as we discuss below.

\subsection{Height measurement precision}

The variability in the field-measured tree heights was significantly greater for trees above the mean canopy height. We note that the imprecision of height measurements causes a small error $(5 \%$ to $9 \%$, mean of $6 \%$ ) in transect-level biomass.

Most sources of height measurement error are pronounced for large trees. We recognize five sources of uncertainty that contribute to the precision of field height measurements. Issues in the field measurement of height are offset between measured distance and crown-top position, tree-top occlusion, ground slope, obstacles for distance measurements, and clinometer operator error. 

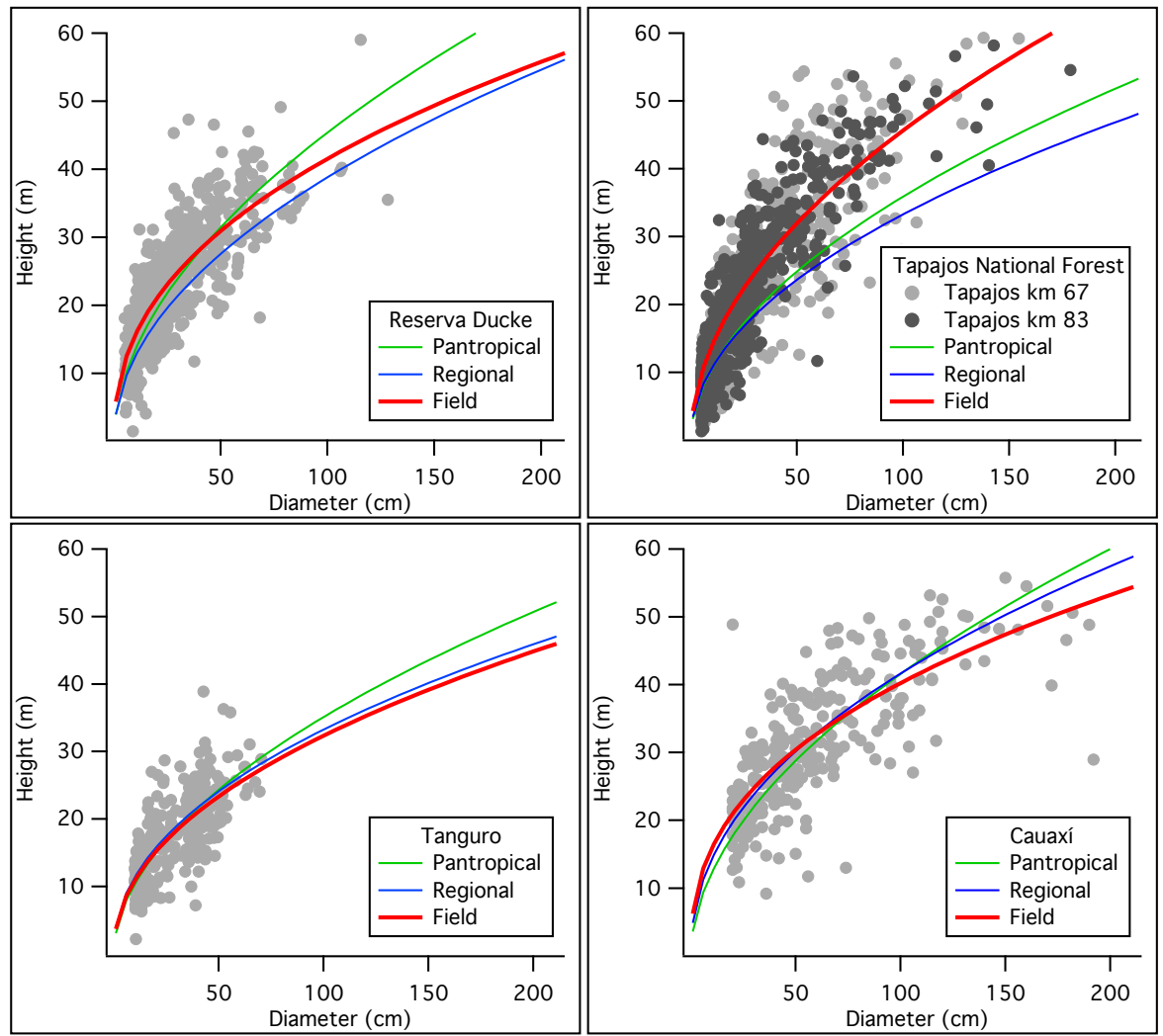

Fig. 4. Comparison of allometric scaling relationships. Regional and pantropical allometries from Feldpausch et al. (2011) that include sitespecific climatic and structural parameters (reported in Table 2 and Table 3, respectively) and a site-specific allometry (field) based on height and diameter measurements at all sites: Reserva Ducke, Tapajos, Tanguro and Cauaxí.

Differences between the distance measured and the true horizontal distance to the crown can cause an unbiased error in height measurement. It is equally likely that distances are overestimated as underestimated. In obvious cases, such as where the trunk was sloped, or the canopy was offset from the trunk location, we attempted to correct the distance measurement in the field. The uncertainty associated with displacement of crown tops from trunk locations is most pronounced for the largest trees with large crowns (Andersen et al., 2006).

As the distance between the observer and the tree increases, visibility is reduced by surrounding vegetation resulting in tree-top occlusion. This effect was most pronounced for large-crowned trees with relatively flat crowns. For the ground-based observer, the flat-topped canopies of some broadleaf trees were indistinguishable from a more rounded shape, even at large distances without obstructions. The observer made assumptions about crown shape to approximate the total tree height. This error was reduced by increasing the distance from the tree and diminishing the extent that the view of the tallest crown point would be occluded by the crown itself.
Ground slope, if not properly accounted for, will cause a systematic overestimation of the distance between the observer and the stem measured. This overestimation of distance will result in an overestimate of height. This was only an issue for sites that were measured using a clinometer (Tapajos sites, Reserva Ducke, Tanguro). The laser range finder automatically corrects for slope when calculating horizontal distance. Of the four sites measured with a clinometer, only Reserva Ducke had notable slopes, and for this site the slope of the measurement tape was measured and the distance corrected.

The distance measurement is also affected by obstacles. When pulling a measuring tape through the forest it is necessary to weave through understory vegetation and other trees. This will create a small bias towards overestimating distance. Given that the individual making measurements must have a line of sight with the trunk base, or a ground position directly beneath the canopy maximum, this line of sight can also be used to pass the measuring tape. The measuring tape is always pulled taught and leveled before any reading is made to minimize the potential for overestimating distance. 

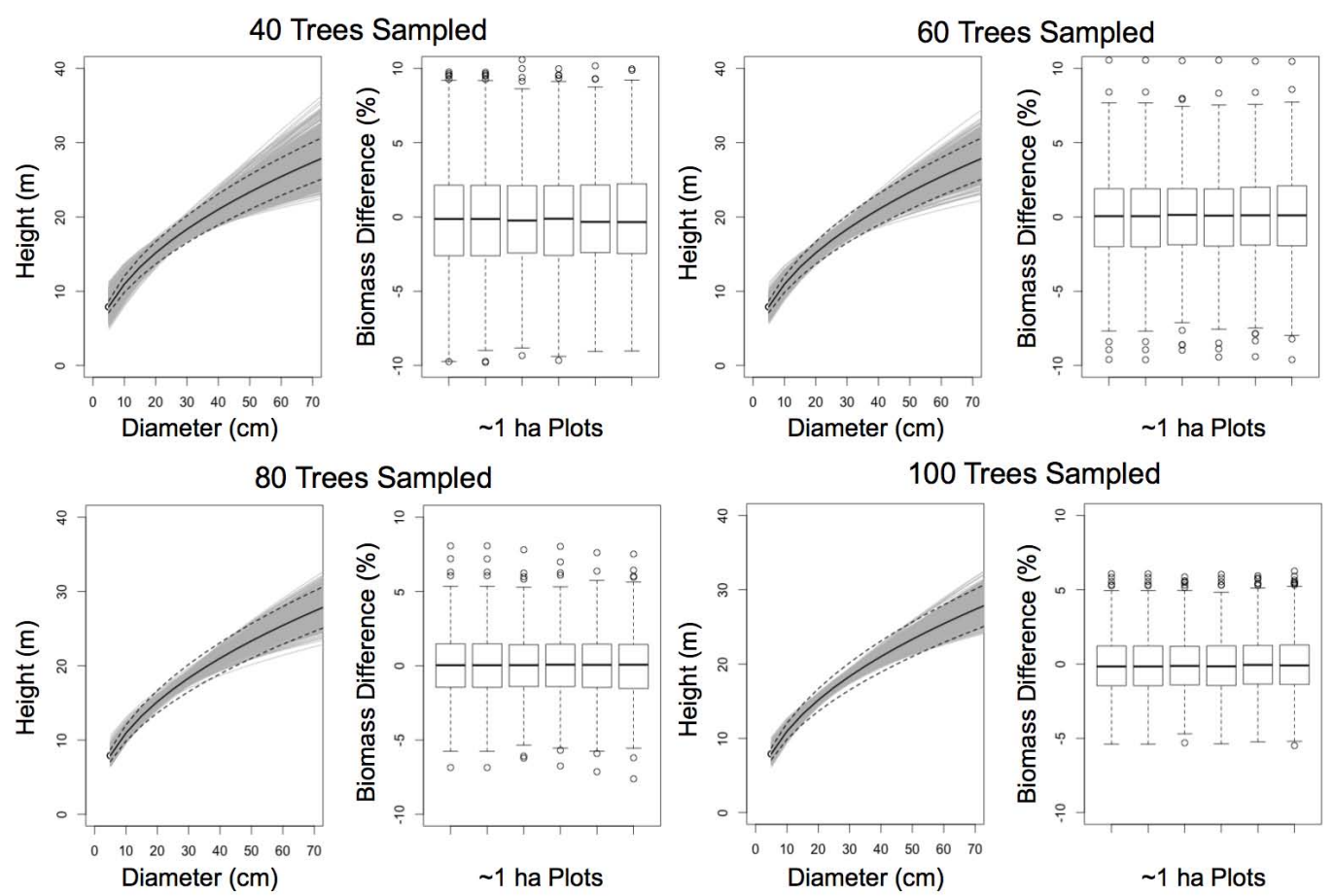

Fig. 5. Effect of sample size on the resulting diameter-to-height allometric equation for Tanguro. Dashed lines represent a range of $10 \%$ difference in height. The grey area represents the range of bootstrap estimates. Boxplots show the variability in six 1 ha transect biomass estimates due to differences in the predicted tree height based on sample sizes of 40, 60, 80 and 100 stems.

Because of the perceived difficulty of measuring distance properly, many researchers prefer to use laser range finders or hypsometers (RAINFOR, 2009; Chave, 2005 - CTFS). However, it is worthwhile to point out that replacement of the tape and clinometer with a laser range finder does not preclude two major sources of error, offset between measured distance and crown-top position and tree-top occlusion. Identifying the correct tree-top position is the most difficult part of the measurement, and the more sophisticated instrumentation does nothing to improve this situation. In addition, the laser range finder adds a source of error. Specifically, the presence of dense understory vegetation may lead to underestimation of the distance between the observer and the tree of interest because of intervening obstacles inadvertently hit by the laser beam (i.e., leaves, branches). This uncertainty led to our preference for direct measurement using a tape measure at the more recently studied sites.

As with any measurement, operator error may occur. The largest differences in repeat height measurement may have been cases of mistaken identity (the crown of one tree was thought to be another). In a comparison of multiple height measurement techniques, Rennie (1979) showed that measurements made with clinometers were generally precise, but showed a slight underestimation bias for the tallest trees measured. However, when conducting a similar experiment Williams et al. (1994) showed a slight underestimation bias for small trees (less than $10 \mathrm{~m}$ ) and an overestimation bias for tall trees (greater than $20 \mathrm{~m}$ ). This overestimation bias was more pronounced for conifers than for all species, though the $95 \%$ confidence interval contained zero in all cases.

Recently, researchers have proposed an alternative method of height estimation ("the sine method") that does not require a horizontal distance measurement (Goodwin, 2004). This measurement uses a single distance and angle measurement to the highest point on the tree crown using a laser range finder or hypsometer, and a second measurement of distance and angle to the tree base. The vertical component of each measurement can be calculated by the equipment used and added to yield the total tree height. Larjavaara and MullerLandau (2013) compared this technique to the traditional tangent method used here and showed that the tangent method resulted in large errors, but unbiased results, consistent with results presented here. The sine method, however, resulted in underestimation of height by an average of $20 \%$.

\subsection{Height measurement accuracy}

The errors that contribute to field height measurement precision likewise contributed to measurement accuracy. Errors due to slope and due to obstacles when measuring distance will result in overestimation of the horizontal distance and lead to overestimation of tree height. Errors associated with the difficulty in seeing the tree top may result in underestimation or overestimation of tree height. To assess the accuracy 
of height measurement, field-measured heights were compared with lidar-estimated heights for emergent stems. Errors that contribute to lidar height error are overtopping of canopy stems, geolocation error, and lidar measurement error (Andersen et al., 2006; Popescu et al., 2002; Ørka et al., 2010).

Overtopping of canopies will result in a positive bias for lidar heights. This bias is due to the use of the CHM for extracting lidar heights. In our study, this model filtered for the tallest returns within a given $1 \mathrm{~m}$ grid cell. By filtering for the highest points, only trees whose canopies are not overtopped by surrounding crowns or by taller vegetation are correctly measured (see Fig. 1). This was taken into account when making a comparison between lidar and field heights by only comparing emergent stems.

Error in lidar estimations of height are also expected due to error in crown position. Tree canopy positions were referenced to the trunk position, which was referenced to the transect. Transects were geolocated using a combination of differential GNSS and navigational GPS measurements. Errors are present in each of these components that may cancel or compound each other to affect canopy position. These errors will have the largest impact on the smallest crowns. Emergent crowns tend to have large canopies that extend beyond the extent of location error. Emergent crowns average $6.2 \mathrm{~m}$ radius, while the stem RMS error in horizontal position was about $5.7 \mathrm{~m}$. This, in combination with the lack of local overtopping vegetation, results in more accurate lidar heights for the tallest and largest canopies (i.e., emergent trees) compared to smaller, lower canopies.

The expected vertical uncertainty of the lidar instrument is $15 \mathrm{~cm}$. The precision of field measurement was $3.8 \mathrm{~m}$ for trees within $10 \mathrm{~m}$ below the dominant canopy height, and greater than $8.2 \mathrm{~m}$ for trees above this height. Previous research has shown a consistent bias toward underestimation of height using lidar remote sensing in both broadleaf and coniferous trees. Gaveau and Hill (2003) showed an underestimation of $2.1 \mathrm{~m}$ for broadleaf trees, and Rönnholm (2004) showed an underestimation of $0.7-1.4 \mathrm{~m}$ somewhat dependent on tree species (Gaveau and Hill, 2003; Rönnholm et al., 2004; Wang and Glenn, 2008). Clark et al. (2004) found similar results for a tropical forest in Costa Rica. Gaveau and Hill (2003) showed that this underestimate of height is likely due to penetration of the lidar signal into the upper section of the canopy. However, this potential bias is small when compared to the uncertainty in field estimates of canopy tree height.

Our field heights were consistently higher than lidar heights for emergent trees. This is consistent with Williams (1994) results showing height measured with a clinometer to be biased about $1 \mathrm{~m}$ high on average for trees over $20 \mathrm{~m}$, and in opposition to the results of Rennie (1979) showing a slight low bias. This result is also consistent with results showing underestimation of height based on lidar CHMs due to penetration of the outer canopy surface (Gaveau and Hill,
2003). Whether this difference is due to true overestimation of height in the field or due to lidar penetration is unclear. This $1-2 \mathrm{~m}$ potential bias represents a difference of less than $6 \%$ of the mean height of emergent trees.

The accuracy and precision of lidar- and field-measured heights further affects our ability to measure changes in height over short time spans. Where lidar data is available it provides a more accurate source of height information for canopy and emergent stems. This improved accuracy and precision reduce the variability in height measurement. Given that height growth in gaps is greater than $1 \mathrm{my}^{-1}$ (Fredericksen and Pariona, 2002), significant changes in height should be distinguishable over shorter time spans using lidar as compared to field data once trees exceed a maximum height accessible by extensible measuring poles (10 to $15 \mathrm{~m})$.

\subsection{Biomass precision}

The effect of height imprecision on biomass is approximately $6 \%$ and the effect of potential inaccuracy on biomass is smaller (4.1\% at Reserva Ducke and $3.5 \%$ at Tapajos) despite the large uncertainty in the height of tall trees $(8-10.5 \mathrm{~m}$ for trees greater than $34 \mathrm{~m}$ ). The uncertainty in biomass on the plot basis is less that the uncertainty of height in the largest trees partly because the measurement errors cancel each other out. More importantly, the errors are greatest for the largest trees, and most biomass was in mediumstatured trees (canopy stratum) that had smaller relative error in height measurements.

Height has been repeatedly shown to improve biomass estimates as compared with diameter only in allometric relations for tropical forest trees (Chave et al., 2005; Feldpausch et al., 2012; Lima et al., 2012; Maia Araújo et al., 1999; Vieira et al., 2008). This result is obvious from inspection of height-diameter relations (Fig. 6). All four areas studied here are moist tropical forests within the Brazilian Amazon, but their diameter-height allometries vary significantly. Some of this variability in diameter-height allometries is believed to be due to climatic variability (Feldpausch et al., 2011). Tree architecture and variable species assemblages are also important drivers. Vieira et al. (2008) used two diameter-only allometries to estimate biomass in the Brazilian Atlantic Forest (Chave et al., 2005; Chambers et al., 2001) and found overestimates of biomass by $52 \%$ and $68 \%$, respectively.

We compared a number of approaches to biomass estimation using both height and diameter information for the four areas in our study (Table 5). Applying diameter-only equations to estimate biomass led to variation of between $4 \%$ and $52 \%$ from our reference case (Table 3, bold values). The largest effect was found at Tanguro, which has the smaller stature of a transitional forest. Other areas generally showed differences of less than $10 \%$, though the Chambers et al. (2001) allometry performed significantly worse at Cauaxí. 
Table 5. Above-ground biomass estimate based on various allometries for the field sites detailed here. The two Tapajos sites (Tapajos km 67 and Tapajos $\mathrm{km} \mathrm{83)}$ are combined due to minimal difference in site-specific allometries. The biomass allometries applied are the Chave et al. (2005) Model I allometry including wood density, diameter and field-measured tree height ("Field Ht"); the Chave et al. (2005) Model I allometry with site-specific model of diameter-height ("Modeled Ht"); the Chave et al. (2005) Model II equation without a height term ("Chave - D"); the Chambers et al. (2001) allometry based purely on diameter; the Chave et al. (2005) Model I allometry including height modeled using the Feldpausch et al. (2011) regional equation ("Regional"); and the Chave et al. (2005) Model I allometry including height modeled using the Feldpausch et al. (2011) pantropical height allometry ("Pantropic"). Percent difference from the field height value is shown for Reserva Ducke and Tapajos, and from the modeled height for Tanguro and Cauaxi. This is referred to as the reference case in the text and emboldened here.

\begin{tabular}{lrrrrrr}
\hline Site & Field Ht & Modeled Ht & Chave - D & Chambers & Regional & Pantropic \\
\hline Reserva Ducke & $\mathbf{3 6 1}$ & $363(+1 \%)$ & $382(+6 \%)$ & $346(-4 \%)$ & $317(-12 \%)$ & $358(-1 \%)$ \\
Tapajos & $\mathbf{3 0 7}$ & $312(+2 \%)$ & $317(+4 \%)$ & $277(-10 \%)$ & $231(-25 \%)$ & $243(-21 \%)$ \\
Tanguro & NA & $\mathbf{1 2 1}$ & $170(+40 \%)$ & $184(+52 \%)$ & $126(+4 \%)$ & $122(+1 \%)$ \\
Cauaxi & NA & $\mathbf{3 2 8}$ & $360(+10 \%)$ & $261(-21 \%)$ & $331(+1 \%)$ & $322(-2 \%)$ \\
\hline
\end{tabular}

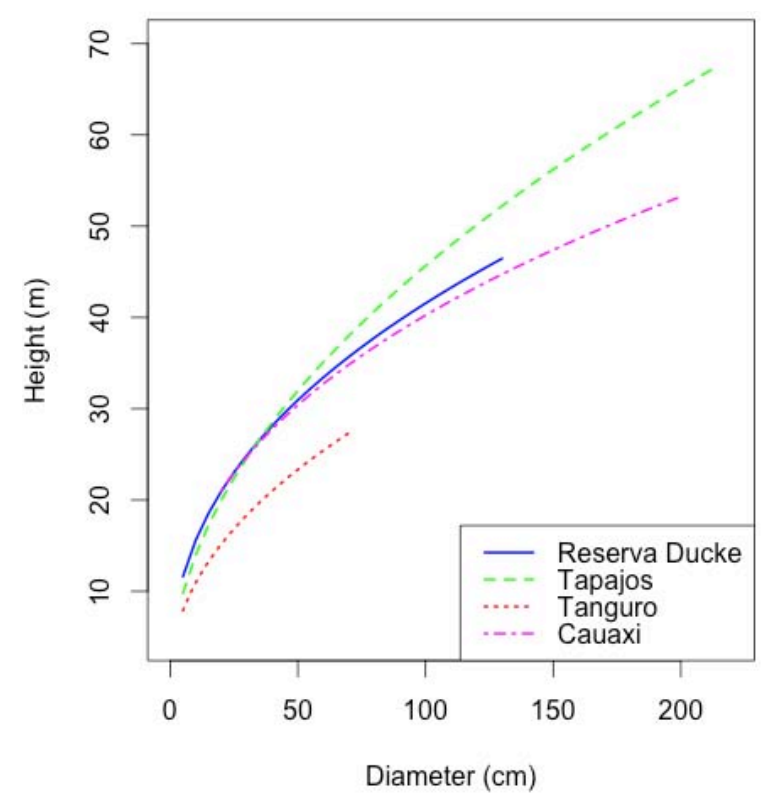

Fig. 6. Comparison of site-specific diameter-height allometries for the four study areas.

\subsection{Height allometries}

We evaluated the overall accuracy of the Feldpausch et al. (2011) regional and pantropical height allometries based on only four areas. In three cases the relations worked well, but based on the substantial differences at one of the four areas we advise caution when applying generic diameterheight allometries. A sensitivity analysis conducted for Tapajos shows the inaccuracy in the diameter-to-height allometry is caused by variation in climatic variables, most importantly, dry season length. Applying the climatic variables specific to Manaus (which has a significantly shorter dry season) curiously yielded a better fit to the Tapajos data. This sug- gests that the inclusion of climatic parameters may not be universally advantageous.

The potential for inaccuracy of regional and pantropical allometries suggests that site-specific allometries are preferable for accurate estimates of biomass. When formulating site-specific allometries it is necessary to take into account the distribution of biomass at the site. The sampling scheme described in the methods section weights diameter classes by their proportional biomass. The weighting scheme presented was applicable to all areas despite the variability in diameter ranges. Site-specific allometries estimate biomass within $2 \%$ at Reserva Ducke and Tapajos compared to our reference case where all tree heights were measured.

\subsection{Height allometric optimization}

Given the potential for error using regional diameter-height allometries and the importance of height in estimating biomass it is advantageous to have site-specific diameterheight allometries. Because height measurements are time consuming, it is important to minimize the number of height measurements necessary to define an allometry to within a target uncertainty. Sample sizes tested were limited by the small number of trees in the largest diameter classes. While allometries fit to Tapajos data were well constrained at the largest diameter sizes, allometries fit to data from Reserva Ducke were not. However, the variability in predicted height for the largest diameter stems made little difference in the predicted biomass at the transect scale due to the extremely small number of individuals in the largest classes. The RAINFOR network has recommended a stratified sample for measuring heights (RAINFOR, 2009) with height measurements for a total of 40 trees divided equally between four diameter classes: $10-20 \mathrm{~cm}, 20-30 \mathrm{~cm}, 30-50 \mathrm{~cm}$, and $>50 \mathrm{~cm}$. This smaller sample size would result in a $95 \%$ confidence intervals of transect-level biomass approximately twice that of the 100-tree sample suggested here (see Fig. 5). 


\section{Conclusions}

We found that the precision of height measurements of individual trees ranged from 3 to $20 \%$ of total height, leading to a mean error of $16 \%$ in the estimate of individual tree biomass. When scaled to the plot level, this lack of precision of height measurements led to 5-6\% uncertainty in overall plot biomass. Ground-based measurements of height exceeded airborne lidar measurements of height by an average of $1.4 \mathrm{~m}$. Whether this is due to overestimation of field height, underestimation by lidar, or a combination of these factors is unclear. If this represents a positive bias in field height, then overall plot-level biomass based on field measurements would be biased $4 \%$ high.

The use of diameter-based allometries, including pantropical and regional height-diameter relationships led to large biases for individual site biomass when compared to local field height measurements (Fig. 4): $-25 \%$ and $-12 \%$ at Tapajos and Reserva Ducke, respectively, using the Feldpausch regional allometry. The pantropical allometry performed better at Reserva Ducke $(-1 \%)$ but maintained a large bias at Tapajos $(-21 \%)$. For other sites, the regional and pantropical allometries were within $4 \%$ of field-based height-diameter relationships. We recommend caution when employing regional and global relations and suggest that field work can be optimized by measuring the height of approximately 100 individuals to build a site-specific height-diameter allometry. This approach reduced the potential uncertainty in the biomass of 1 ha plots due to the diameter-height allometry to an average of $4.5 \%$ for all sites studied (Fig. 5).

Regional and global biomass estimates (e.g., Asner et al., 2011; Baccini et al., 2012; Saatchi et al., 2011) that use remote sensing and statistical algorithms for scaling ultimately depend upon the measurements of individual trees. Tree biomass estimates rely on field height measurements or estimates based on diameter-height allometries. Based on our work at sites in the Brazilian Amazon it is unclear whether heights of trees above mean canopy height were biased or merely imprecise. The majority of sources of field height error tend toward overestimation of height, whereas lidar has been shown to underestimate height. This potential bias in field height results in an overestimate of biomass by about $4 \%$. This bias is small considering all of the uncertainties involved in field biomass estimates and is drawn from a limited set of measurements. However, given the availability of airborne lidar height estimates at an increasing number of tropical field sites, we recommend further investigation of this potential bias because of the important role of tropical forests in the global carbon cycle.
Acknowledgements. The authors would like to thank T. Feldpausch and two anonymous reviewers for their help in improving this manuscript. This research was supported by NASA grants NNG06GE11A, NNX09AI33G, NNG04G073G and NNX06AH36G, NSF grant DEB0721140 and USAid Sustainable Landscapes.

Edited by: M. Williams

\section{References}

Andersen, H.-E., Reutebuch, S. E., and McGaughey, R. J.: A rigorous assessment of tree height measurements obtained using airborne lidar and conventional field methods, Can. J. Remote Sens., 32, 355-366, 2006.

Asner, G. P., Palace, M., Keller, M., Pereira Jr., R., Silva, J. N. M., and Zweede, J. C.: Estimating canopy structure in an Amazon forest from laser rangefinder and IKONOS satellite observations. Biotropica, 34, 483-492, 2002.

Asner, G. P., Mascaro, J., Muller-Landau, H. C., Vieilledent, G., Vaudry, R., Rasamoelina, M., Hall, J. S., and Breugel, M. V.: A universal airborne LiDAR approach for tropical forest carbon mapping, Oecologia, 168, 1147-1160, doi:10.1007/s00442-0112165-z, 2011.

Asner, G., Palace, M., Keller, M., Pereira, M., Silva, J., and Zweede, J.: LBA-ECO TG-07 Tree Geometry in an Undisturbed Forest in Cauaxi, Para, Brazil, Data set available at: http://daac.ornl.gov, from Oak Ridge National Laboratory Distributed Active Archive Center, Oak Ridge, Tennessee, USA http://dx.doi.org/10.3334/ ORNLDAAC/1063 (last access: 11 January 2013), 2012.

Baccini, A., Goetz, S. J., Walker, W. S., Laporte, N. T., Sun, M., Sulla-Menashe, D., Hackler, J., Beck, P., Dubayah, R., and Friedl, M. A.: Estimated carbon dioxide emissions from tropical deforestation improved by carbon-density maps, Nature Clim. Change, 2, 182-185, 2012.

Balch, J. K., Nepstad, D. C., Brando, P. M., Curran, L. M., Portela, O., de Carvalho Jr., O., and Lefebvre, P.: Negative fire feedback in a transitional forest of southeastern Amazonia, Glob. Change Biol., 14, 2276-2287, 2008.

Balch, J. K., Nepstad, D. C., Curran, L., Brando, P. M., Portela, O., Guilherme, P., Reuning-Scherer, J. D., and de Carvalho Jr., O.: Size, species, and fire behavior predict tree and liana mortality from experimental burns in the Brazilian Amazon, Forest Ecol. Manag., 261, 68-77, 2010.

Basuki, T. M., van Laake, P. E., Skidmore, A. K., and Hussin, Y. A. Allometric equations for estimating the above-ground biomass in tropical lowland Dipterocarp forests, Forest Ecol. Manag., 257, 1684-1694, doi:10.1016/j.foreco.2009.01.027, 2009.

Campbell, D. G., Daly, D. C., Prance, G. T., and Maciel, U. N.: Quantitative ecological inventory of terra firme and várzea tropical forest on the Rio Xingu, Brazilian Amazon, Brittonia, 38, 369-393, 1986.

Chambers, J. Q., Santos, J., Ribeiro, R., and Higuchi, N.: Tree damage, allometric relationships, and above-ground net primary production in central Amazon forest, Forest Ecol. Manag., 152, 73 84, 2001.

Chauvel, A., Lucas, Y., and Boulet, R.: On the genesis of the soil mantle of the region of Manaus, Central Amazonia, Brazil, Experientia, 43, 234-241, doi:10.1007/BF01945546, 1987. 
Chave, J.: Measuring tree height for tropical forest trees: A field manual for the CTFS sites, www.ctfs.si.edu (last access: 23 May 2013), 2005.

Chave, J., Andalo, C., Brown, S., Cairns, M. A., Chambers, J. Q., Eamus, D., Fölster, H., Fromard, F., Higuchi, N., Kira, T., Lescure, J.-P., Nelson, B. W., Ogawa, H., Puig, H., Riéra, B., and Yamakura, T.: Tree allometry and improved estimation of carbon stocks and balance in tropical forests, Oecologia, 145, 87-99, doi:10.1007/s00442-005-0100-x, 2005.

Chave, J., Condit, R. S., Lao, S., Caspersen, J., Foster, R. B., and Hubbell, S. P.: Spatial and temporal variation of biomass in a tropical forest: results from a large census plot in Panama, J. Ecol., 91, 240-252, 2003.

Clark, D. B. and Kellner, J. R.: Tropical forest biomass estimation and the fallacy of misplaced concreteness, edited by: Palmer, M., J. Veg. Sci., 23, 1191-1196, doi:10.1111/j.16541103.2012.01471.x, 2012.

Clark, M., Clark, D., and Roberts, D. A.: Small-footprint lidar estimation of sub-canopy elevation and tree height in a tropical rain forest landscape, Remote Sens. Environ., 91, 68-89, 2004.

Cook, B., Corp, L., Nelson, R., Middleton, E., Morton, D., McCorkel, J., Masek, J., Ranson, K., Ly, V., and Montesano, P.: NASA Goddard's LiDAR, Hyperspectral and Thermal (G-LiHT) Airborne Imager, Remote Sens., 5, 4045-4066, doi:10.3390/rs5084045, 2013.

De Oliveira, A. A. and Mori, S. A.: A central Amazonian terra firme forest, I. High tree species richness on poor soils, Biodivers Conserv., 8, 1219-1244, 1999.

Feldpausch, T. R., Banin, L., Phillips, O. L., Baker, T. R., Lewis, S. L., Quesada, C. A., Affum-Baffoe, K., Arets, E. J. M. M., Berry, N. J., Bird, M., Brondizio, E. S., de Camargo, P., Chave, J., Djagbletey, G., Domingues, T. F., Drescher, M., Fearnside, P. M., França, M. B., Fyllas, N. M., Lopez-Gonzalez, G., Hladik, A., Higuchi, N., Hunter, M. O., Iida, Y., Salim, K. A., Kassim, A. R., Keller, M., Kemp, J., King, D. A., Lovett, J. C., Marimon, B. S., Marimon-Junior, B. H., Lenza, E., Marshall, A. R., Metcalfe, D. J., Mitchard, E. T. A., Moran, E. F., Nelson, B. W., Nilus, R., Nogueira, E. M., Palace, M., Patiño, S., Peh, K. S.H., Raventos, M. T., Reitsma, J. M., Saiz, G., Schrodt, F., Sonké, B., Taedoumg, H. E., Tan, S., White, L., Wöll, H., and Lloyd, J.: Height-diameter allometry of tropical forest trees, Biogeosciences, 8, 1081-1106, doi:10.5194/bg-8-1081-2011, 2011.

Feldpausch, T. R., Lloyd, J., Lewis, S. L., Brienen, R. J. W., Gloor, M., Monteagudo Mendoza, A., Lopez-Gonzalez, G., Banin, L., Abu Salim, K., Affum-Baffoe, K., Alexiades, M., Almeida, S., Amaral, I., Andrade, A., Aragão, L. E. O. C., Araujo Murakami, A., Arets, E. J. M. M., Arroyo, L., Aymard C., G. A., Baker, T. R., Bánki, O. S., Berry, N. J., Cardozo, N., Chave, J., Comiskey, J. A., Alvarez, E., de Oliveira, A., Di Fiore, A., Djagbletey, G., Domingues, T. F., Erwin, T. L., Fearnside, P. M., França, M. B., Freitas, M. A., Higuchi, N., E. Honorio C., Iida, Y., Jiménez, E., Kassim, A. R., Killeen, T. J., Laurance, W. F., Lovett, J. C., Malhi, Y., Marimon, B. S., Marimon-Junior, B. H., Lenza, E., Marshall, A. R., Mendoza, C., Metcalfe, D. J., Mitchard, E. T. A., Neill, D. A., Nelson, B. W., Nilus, R., Nogueira, E. M., Parada, A., Peh, K. S.-H., Pena Cruz, A., Peñuela, M. C., Pitman, N. C. A., Prieto, A., Quesada, C. A., Ramírez, F., Ramírez-Angulo, H., Reitsma, J. M., Rudas, A., Saiz, G., Salomão, R. P., Schwarz, M., Silva, N., Silva-Espejo, J. E., Silveira, M., Sonké, B., Stropp, J.,
Taedoumg, H. E., Tan, S., ter Steege, H., Terborgh, J., TorelloRaventos, M., van der Heijden, G. M. F., Vásquez, R., Vilanova, E., Vos, V. A., White, L., Willcock, S., Woell, H., and Phillips, O. L.: Tree height integrated into pantropical forest biomass estimates, Biogeosciences, 9, 3381-3403, doi:10.5194/bg-9-33812012, 2012.

Fredericksen, T. and Pariona, W.: Effect of skidder disturbance on commercial tree regeneration in logging gaps in a Bolivian tropical forest, Forest Ecol. Manag., 171, 223-230, 2002.

Gaveau, D. and Hill, R. A.: Quantifying canopy height underestimation by laser pulse penetration in small-footprint airborne laser scanning data, Can. J. Remote Sens., 29, 650-657, 2003.

Gibbs, H. K., Brown, S., Niles, J. O., and Foley, J. A.: Monitoring and estimating tropical forest carbon stocks: making REDD a reality, Environ. Res. Lett., 2, 045023, doi:10.1088/17489326/2/4/045023, 2007.

Goodwin, A. N.: Measuring Tall Tree Heights from the Ground, Tasforests, 15, 85-97, 2004.

Hijmans, R. J., Cameron, S. E., Parra, J. L., Jones, P. G., and Jarvis, A.: Very high resolution interpolated climate surfaces for global land areas, Int. J. Climatol., 25, 1965-1978, doi:10.1002/joc.1276, 2005.

Houghton, R. A.: Aboveground Forest Biomass and the Global Carbon Balance, Glob. Change Biol., 11, 945-958, 2005.

Larjavaara, M. and Muller-Landau, H. C.: Measuring Tree Height: A Quantitative Comparison of Two Common Field Methods in a Moist Tropical Forest, Meth. Ecol. Evol., 4, 793-801, doi:10.1111/2041-210X.12071, 2013.

Le Toan, T., Quegan, S., Davidson, M. W. J., Balzter, H., Paillou, P., Papathanassiou, K., Plummer, S., Rocca, F., Saatchi, S. S., Shugart, H., and Ulander, L.: The BIOMASS mission: Mapping global forest biomass to better understand the terrestrial carbon cycle, Remote. Sens. Environ., 115, 2850-2860, doi:10.1016/j.rse.2011.03.020, 2011.

Lefsky, M. A., Harding, D. J., Keller, M., Cohen, W. B., Carabajal, C. C., Espirito-Santo, F., Hunter, M. O., and De Oliveira Jr., R. C.: Estimates of forest canopy height and aboveground biomass using ICESat, Geophys. Res. Lett., 32, doi:10.1029/2005GL023971, 2005.

Lefsky, M. A., Keller, M., Pang, Y., de Camargo, P. B., and Hunter, M. O.: Revised method for forest canopy height estimation from Geoscience Laser Altimeter System waveforms, J. Appl. Remote Sens., 1, 013537, doi:10.1117/1.2795724, 2007.

Lima, A., Suwa, R., de Mello Ribeiro, G., Kajimoto, T., dos Santos, J., da Silva, R. P., de Souza, C. A. S., de Barros, P. C., Noguchi, H., Ishizuka, M., and Higuchi, N.: Allometric models for estimating above- and below-ground biomass in Amazonian forests at São Gabriel da Cachoeira in the upper Rio Negro, Brazil, Forest Ecol. Manag., 277, 163-172, 2012.

Litton, C. M. and Kauffman, J. B.: Allometric Models for Predicting Aboveground Biomass in Two Widespread Woody Plants in Hawaii, Biotropica, 40, 313-320, doi:10.1111/j.17447429.2007.00383.x, 2008.

Maia Araújo, T., Higuchi, N., and Andrade de Carvalho Júnior, $\mathrm{J}$.: Comparison of formulae for biomass content determination in a tropical rain forest site in the state of Pará, Brazil, Forest Ecol. Manag., 117, 43-52, doi:10.1016/S0378-1127(98)004708, 1999. 
Molto, Q., Rossi, V., and Blanc, L.: Error propagation in biomass estimation in tropical forests, edited by R. Freckleton, Methods Ecol. Evol., 4, 175-183, doi:10.1111/j.2041-210x.2012.00266.x, 2012.

Nelson, R.: Model effects on GLAS-based regional estimates of forest biomass and carbon, Int. J. Remote Sens., 31, 1359-1372, 2010.

Ørka, H. O., Næsset, E., and Bollandsås, O. M.: Effects of different sensors and leaf-on and leaf-off canopy conditions on echo distributions and individual tree properties derived from airborne laser scanning, Remote Sens. Environ., 114, 1445-1461, doi:10.1016/j.rse.2010.01.024, 2010.

Pereira, R., Zweede, J., Asner, G. P., and Keller, M.: Forest canopy damage and recovery in reduced-impact and conventional selective logging in eastern Para, Brazil, Forest Evol. Manag., 168, 77-89, 2002.

Popescu, S., Wynne, R., and Nelson, R.: Estimating plot-level tree heights with lidar: local filtering with a canopy-height based variable window size, Comput. Electron. Agr., 37, 71-95, 2002.

Radambrasil: Levantamento de Recursos Naturais. Rio de Janeiro/Vitória: geologia, geomofologia, pedologia, vegetação e uso potencial da terra, Ministério de Minas e Energia, folhas SF., 1983.

RAINFOR: Field Manual for Plot Establishment and Remeasurement, www.rainfor.org (last access: 23 May 2013), 2009.

Rennie, J. C.: Comparison of Height-Measurement Techniques in a Dense Loblolly Pine Plantation, South J. Appl. For., 3, 146-148, 1979.

Rönnholm, P., Hyyppä, J., Hyyppä, H., Haggrén, H., Yu, X., and Kaartinen, H.: Calibration of laser-derived tree height estimates by means of photogrammetric techniques, Scand. J. Forest Res., 19, 524-528, doi:10.1080/02827580410019436, 2004.

Saatchi, S. S., Harris, N. L., Brown, S., Lefsky, M., Mitchard, E. T. A., Salas, W. A., Zutta, B. R., Buermann, W., Lewis, S. L., Hagen, S., Petrova, S., White, L., Silman, M., and Morel, A.: Benchmark map of forest carbon stocks in tropical regions across three continents, P. Natl. Acad. Sci. USA, 108, 98999904, doi:10.1073/pnas.1019576108, 2011.
Schreuder, H. T., Banyard, S. G., and Brink, G. E.: Comparison of three sampling methods in estimating stand parameters for a tropical forest, Forest Ecol. Manag., 21, 119-127, 1987.

Silver, W. L., Neff, J., Mcgroddy, M., Veldkamp, E., Keller, M., and Cosme, R.: Effects of Soil Texture on Belowground Carbon and Nutrient Storage in a Lowland Amazonian Forest Ecosystem, Ecosystems, 3, 193-209, doi:10.1007/s100210000019, 2000.

Vieira, S. A., Alves, L. F., Aidar, M., Araujo, L. S., Baker, T. R., Batista, J. L. F., Campos, M. C., de Camargo, P. B., Chave, J., Delitti, W. B. C., Higuchi, N., Honorio, E., Joly, C. A., Keller, M., Martinelli, L. A., de Mattos, E. A., Metzker, T., Phillips, O., dos Santos, F. A. M., Shimabukuro, M. T., Silveira, M., and Trumbore, S. E.: Estimation of biomass and carbon stocks: the case of the Atlantic Forest, Biota Neotropica, 8, 21-29, doi:10.1590/S1676-06032008000200001, 2008.

Vieira, S., de Camargo, P. B., Selhorst, D., Silva, R., Hutyra, L. R., Chambers, J. Q., Brown, I., Higuchi, N., Santos, J., Wofsy, S. C., Trumbore, S., and Martinelli, L. A.: Forest structure and carbon dynamics in Amazonian tropical rain forests, Oecologia, 140, 112, doi:10.1007/s00442-004-1598-z, 2004.

Wang, C. and Glenn, N. F.: A linear regression method for tree canopy height estimation using airborne lidar data, Can. J. Remote Sens., 34, 217-227, 2008.

Watson, R. T.: Land Use, Land-Use Change, and Forestry, edited by: Watson, R. T., Noble, I. R., Bolin, B., Ravindranath, N. H., Verardo, D. J., and Dokken, D. J., Cambridge Univ Press, Cambridge. 2000.

Williams, M. S. and Schreuder, H. T.: Guidelines for choosing volume equations in the presence of measurement error in height, Can. J. Forest Res., 30, 306-310, doi:10.1139/x99-215, 2000.

Williams, M. S., Bechtold, W. A., and LaBau, V. J.: Five instruments for measuring tree height: An evaluation, South J. Appl. For., 18, 76-82, 1994.

Zhang, K., Chen, S., Whitman, D., Shyu, M., Yan, J., and Zhang, C.: A progressive morphological filter for removing nonground measurements from airborne LIDAR data, Geoscience and Remote Sensing, IEEE T. Geosci. Remote, 41, 872-882, 2003. 